\title{
2. Jean-Louis Comolli and Jean Narboni: Crossed Lives
}

\begin{abstract}
This chapter charts the intersecting biographies of Jean-Louis Comolli and Jean Narboni in the years leading up to their joint editorship of Cahiers du cinéma. Having first encountered each other in Algeria while the country was still under French colonial rule, the two formed a bond over a shared cinephilia that continues to the present day. Upon moving to Paris, they both joined Cahiers and wrote in defence of the last works of the generation of classical Hollywood filmmakers (Alfred Hitchcock and Howard Hawks, most notably) as well as the rising generation of auteurs belonging to the various international nouveaux cinémas. The chapter ends with a discussion of "Le détour par le direct," Comolli's analysis of the use of direct cinema techniques in both documentary and fiction cinema.
\end{abstract}

Keywords: Jean-Louis Comolli, Jean Narboni, Algeria, Cahiers du cinéma, nouveau cinéma, direct cinema

\section{An Algerian Youth}

Since its initial publication, "Cinéma/idéologie/critique" has appeared in numerous film theory anthologies and is still a standard feature of introduction to film syllabuses internationally. The text, indeed, has sealed Comolli and Narboni's names together in the "pantheon" of film theory. This is a fitting outcome: their relationship dates back to well before their collaboration at Cahiers, and the two have remained lifelong friends long after they left the journal. Comolli and Narboni still regularly see each other today, more than 60 years after first making each other's acquaintance. For approximately a decade at Cahiers, meanwhile, they were close collaborators, working on texts together, deciding on the journal's line in tandem, and watching and discussing films on an almost daily basis. This chapter looks at the

Fairfax, D., The Red Years of Cahiers du Cinéma (1968-1973). Volume I: Ideology and Politics. Amsterdam: Amsterdam University Press, 2021 DOI 10.5117/9789463728508_CHO2 
critical articles they wrote for Cahiers in the period 1962-1969 in order to trace something of the backstory to "Cinéma/idéologie/critique": how they came to defend the type of cinema they did for the reasons that they did in that landmark text. Later, in Part II, I will look closely at the political engagements the journal embarked on within this period, but here it is the critical practice developed by the duo over the course of more than half a decade that is of interest.

Perhaps most fascinating about the relationship between Comolli and Narboni is their shared youth: both are originally from Algeria, part of the pied-noir population, and lived there until decamping for Paris in the early $1960 s$, due to a combination of personal and political factors. In the case of both writers, their time in Algeria had a major effect on their outlook on the world, and it was here that they made each other's acquaintance while studying medicine in Algiers. Narboni is the elder of the two critics by nearly four years, having been born to a middle-class Jewish family in Orléansville (now Chlef) on October 24, 1937, although he primarily grew up in Algiers. Comolli, meanwhile, was born on July 30, 1941 in Philippeville (now Skikda), a mostly Arab coastal town in western Algeria. ${ }^{1}$ Both were exposed to the cinema from a young age. Narboni recalls that after the American liberation of French Algeria in 1942, Hollywood films were shown regularly on Algerian screens, well before they could be projected in metropolitan France, and he remembers seeing the work of Capra, Hawks, Tourneur and Ford with his parents during these years. ${ }^{2}$ Comolli, meanwhile, assiduously visited his town's sole ciné-club, administered by a local high school French teacher, from the early 1950s onwards. As a teen he also took to reading Cahiers $d u$ cinéma, purchasing the single copy of the journal that reached Philippeville's maison de la presse, and he also developed a fondness for jazz, which has remained his other great passion alongside cinema: "I collected records, I listened to a lot of music. I discovered the blues, which marked me a lot, I listened to the jazz that was being exported at this moment: Duke Ellington, Charlie Parker, etc."3

\footnotetext{
1 Biographical details for all the Cahiers writers have been drawn from a variety of sources, including interviews with the persons concerned. As far as secondary sources are concerned, of particular value is the one-volume encyclopedia La critique de cinéma en France, ed. Michel Ciment and Jacques Zimmer (Paris: Ramsay, 1997), especially pp. 280 (for Aumont), 291 (for Bonitzer), 312 (for Comolli), 313-314 (for Daney), 323-324 (for Eisenschitz), 370 (for Narboni) and 375 (for Pierre).

2 Interview with Jean Narboni, March 3, 2014.

3 Interview with Jean-Louis Comolli, May 8, 2011. Comolli frequently contributed articles to Jazz Magazine in the 1960 and has also written books on the subject matter.
} 
In order to take preparatory classes for entering the medicine faculty, Comolli moved to Algiers in the autumn of 1958 - shortly after De Gaulle had seized power in France and when the situation concerning Algeria's political status had reached a boiling point. It was here that he met Narboni, who was already a few years into his studies, as well as Philippe Carles, later an editor ofJazz Magazine, with whom Comolli wrote FreeJazz/BlackPower in $1971 .{ }^{4}$ At the same time, the friendship between Comolli and Narboni was anchored by their frequent attendance at the Algiers ciné-club, which was reputedly the biggest in France at the time (Comolli claims that it had roughly 8000 members), and belonged to the secular left cultural network Peuple et Culture. The Algiers ciné-club was directed by Barthélemy Amengual, a prominent critic in his own right who also moved to Paris upon Algerian independence. Amengual soon tasked the two young cinéphiles with duties convening the screenings, introducing the films or conducting debates afterwards, but the selection of films remained his own. Closely aligned with the Communist Party, Amengual's tastes reflected his political allegiances: the ciné-club's program was dominated by films from Eastern Europe, the Italian neorealist school, and the French poetic realist tradition of Carné and Renoir, while Hollywood films had more difficulty finding favor.

Algeria under French colonial rule was not in a state of strict racial Apartheid, and some Arab-Algerians attended the ciné-club, but its audience was overwhelmingly European and petty-bourgeois in composition. If Amengual's politics came through in his selection of films, they were also manifested in his stubborn insistence on continuing the screenings even in the face of violent conflicts, making the ciné-club a pocket of resistance against the prevailing climate of extremism and civil unrest in the dying days of French rule in Algeria. Narboni remembers that "there were often political incidents the day that there was a ciné-club screening. And often there were people who came into the auditorium, saying 'Yeah, on the streets everybody! Algérie française!' and Amengual would say, 'No, I have my screening.' And often it would happen to be a Soviet film." ${ }^{5}$

While Comolli and Narboni were actively involved in cultural affairs during this period, and while their sentiments were clearly on the left in revulsion at the tactics of the Organisation armée secrète (OAS) and other French Algerian forces, neither of them were politically engaged during their time in Algeria. But the nature of life in a country under such tensions evidently made itself felt on a regular basis, which was recently recounted 
by Comolli in Une terrasse en Algérie, a memoir of his time in Algeria. One particular incident in Philippeville marked Comolli in a more enduring, traumatizing manner. In August 1955, Philippeville was the site of an attack on European residents organized by the Front de libération nationale (FLN) as part of their strategy to trigger a civil war in Algeria, which incited reprisals against the entirety of the Arab population by the French army. Comolli describes his encounter at a young age with this political reality:

Like any other August, I was on the beach, because there was a fishing village close to Philippeville. The fishermen were Arab, but the bosses were from Naples and Sicily, and the village had beautiful beaches. So every day without exception I left home at gam and walked three kilometers to this beach where I spent the whole day swimming. On the evening of this infamous day, I found myself trapped behind a military checkpoint. I immediately understood that something had happened, but I had no idea what it was, because news of the massacre had not reached this beach, which was isolated from the violence. So, because I'm not an Arab, I passed the checkpoint without being arrested and returned to my home town, and there I viewed a scene which overwhelmed me. [...] The riot police held captive a single file of Arab prisoners, all dressed in tattered rags. Some of them were wounded, and this is where my rage against this France dates from, because a French officer asked the Arabs for their papers. Now, these Arabs were probably those who had let off bombs in the city, so they may not have had clean hands, but they gave the officer some vague identity cards and certificates, and, right before my eyes, this officer took their papers and tore them into shreds. This episode was traumatic for me. ${ }^{6}$

Comolli and Narboni both left Algeria voluntarily, shortly before the mass exodus of the pied-noir population in the wake of Algerian independence. Comolli had failed his first-year medicine exams and convinced his father to allow him to enroll in philosophy at the Sorbonne instead, moving to the capital in the rentrée of 1961. Narboni completed his studies in Algiers and moved to Paris shortly afterwards to begin his career. Almost immediately, both young cinephiles gravitated around Langlois' Cinémathèque at the rue d'Ulm. It was here that, after years of reading Cahiers from afar, Comolli and Narboni would come into direct contact with the critics who wrote for the journal.

6 This quote is from the film Jean-Louis Comolli, Filmer pour voir, dir. Ginette Lavigne, 2012. See also Jean-Louis Comolli, Une terrasse en Algérie (Lagrasse: Verdier, 2018), pp. 19-21. 


\section{Critical Beginnings}

In 1961, Comolli had formed a close trio of friends with Jean-André Fieschi, who would also become a long-term writer for Cahiers and later La Nouvelle Critique, and Jean Eustache, who wrote sporadically for Cahiers before becoming one of the most noted filmmakers of the post-nouvelle vague era. All three joined Cahiers through the intermediary of Jean Douchet. At the time, the journal was under the editorship of Éric Rohmer, and Douchet had become something of an unofficial second-in-command at the journal. With the recent elevation of some of its most prominent critics to the status of eminent new wave filmmakers, Douchet saw the need for fresh blood at Cahiers and courted the most assiduous of the cinephiles at the rue d'Ulm to write for the journal. ${ }^{7}$ Comolli published his first article, on Sergeant York by Howard Hawks, in September 1962, barely a year after arriving in Paris, and quickly imposed himself as a regular contributor to the journal. In light of his future activity with Cahiers, overseeing its transformation to an organ of Marxist film theory, the nature of his earliest articles may be a little surprising. The Sergeant York review, "La grandeur du simple," written on the occasion of a retrospective screening of the wartime film, is illustrative. With a clear debt to Rivette's seminal article "Génie de Howard Hawks" (which begins with the resonant declaration: "Evidence is the mark of genius of Hawks" ${ }^{8}$ ), the young Comolli's article argues that the humble simplicity of the character of York (played by Gary Cooper) is an avatar of the straightforward authenticity of Hawks' film style. At the same time, the ambiguity of the director's mise en scène, the ambivalence of his gaze, corresponds to the uncertainty of life itself, as seen through the figure of York. Comolli concludes the article by defining what he sees as the dialectic of Hawks' "grand simplicity": "Man is established, by the purity and the force of Hawks' gaze, such as he may only be in and of himself. This constant presence of the essential confers on the film the grandeur and the simplicity of the immediate revelations of being." 9

An undercurrent of phenomenological humanism can be detected in the Hawks review, but it is thrust into the open with Comolli's second major

7 Comolli, "Yes, we were utopians (Part 1)."

8 Jacques Rivette, "Génie de Howard Hawks," Cahiers du cinéma no. 23 (May 1953), pp. 16-23, here p. 16. Translated as "The Genius of Howard Hawks," trans. Russell Campbell and Marvin Pister, in Jim Hillier (ed.), Cahiers du cinema, the 195os: Neo-Realism, Hollywood, New Wave (Cambridge, MA: Harvard University Press, 1985), pp. 126-131, here p. 126.

9 Jean-Louis Comolli, "Grandeur du simple (Sergeant York)," Cahiers du cinéma no. 135 (September 1962), pp. 54-58, here p. $5^{8}$. 
article, "Vivre le film." Published in March 1963, this 15-page treatise on the essence of the cinema was an ambitious undertaking for a critical novice not yet 22 years old, but it was also a sign that Comolli had been reflecting on the art form long before writing for Cahiers. In this text, he argues for the enrichment of film criticism through philosophical thought, with Heidegger, Merleau-Ponty, Blanchot and even Hegel constituting the most important reference points in this endeavor. In exploring the relation between "art" and "man," Comolli warns against "the totality and objectivity of a scientific method" which would risk negating the mysterious, miraculous nature of artistic creation. ${ }^{10}$ Instead, the art of cinema, seen as "the search for and expression of a truth of man in the world," must be understood in its relation with the individual spectator, even if this means elevating the importance of the subjective relation (art-work/spectator) over the objective relation (art/ man). ${ }^{11}$ In thus arguing for a "phenomenology of the cinema" - the originality of the seventh art being to "plunge us into life and into ourselves more intensely than the other arts, with a more palpable force"12 —Comolli even provides a personal pantheon of favored films, including Rio Bravo, Viaggio in Italia, Tabu, Vertigo, Johnny Guitar and Der Tiger von Eschnapur, as well as a negative pantheon, which contains Citizen Kane, La Notte, The Seventh Seal and (ironically, given Cahiers' later orientation) Battleship Potemkin. Everything about this text, therefore, seems to separate it from the Comolli of "Technique et idéologie." But there is also an uncanny correspondence between this manifesto and his later texts, which tend to recast the logic of "Vivre le film" - its focus on the relationship between film and spectator-in the more Marxist terms of apparatus theory.

Comolli's next few articles under Rohmer's tenure continued in the vein of "Vivre le film." "La présence et l'absence," reviewing Le Petit Soldat, argues that Godard's film "proves, if there was the need for it, that life is richer than thought, and that cinema is richer than language." "Vanité de l'art" treats the "discordant liberty" of Tourneur's mise en scène in The Flame and the Arrow and Great Day in the Morning. "14 "Lautre ailleurs" finds a "new alchemy" of the human body to be present in Bresson's Le Procès

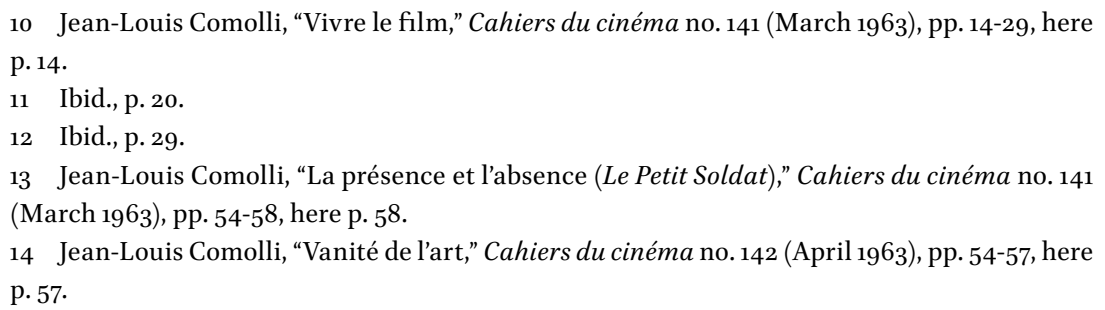


de Jeanne d'Arc. ${ }^{15}$ All three articles attest to a critic growing in confidence, willing to deploy a cluster of artistic and philosophical references, and developing his own writing style and critical outlook. At the same time, Rohmer's standing as editor-in-chief at Cahiers was coming increasingly under threat. In their recent biography of the filmmaker, Antoine de Baecque and Noël Herpe write at great length of the "coup" that deposed Rohmer and replaced him with Jacques Rivette in the summer of $1963 \cdot{ }^{16}$ Concern from certain quarters (Jacques Doniol-Valcroze, Pierre Kast, Michel Delahaye and François Truffaut, in addition to Rivette) at the growing rightwards trajectory of the journal was exacerbated by consternation at the lukewarm support the journal was giving to the nouvelle vague, particularly as the movement came under fire in 1961-1962, and the lack of openness it showed towards modern currents of thinking, all areas in which Rivette promised a sweeping change. Discussions were held with Rohmer about a possible power-sharing arrangement, but the editor was intransigent. The younger crop of critics, including Comolli and Fieschi, were faced with a diabolical choice: support the editors who had given them their start, or side with the current representing modernity and political engagement. Writing from the standpoint of 2009, Comolli relates the position he and his friends found themselves in:

We admired Rohmer and his writing style, as much as Douchet and his critical pertinence. But we also admired the rarer texts written by Rivette, we felt ourselves engaged by the manner in which he thought about the cinema, and the sides he took in the issues of the time. And from my modest position as editorial secretary, I could not avoid seeing how detached the yellow-covered Cahiers were from global movements. ${ }^{17}$

In the end, the "conspirators" made their move: on May 30, a formal letter was addressed to Rohmer informing him of the termination of his role as editor-in-chief at Cahiers, with Rivette taking over as of June 1. Rohmer, however, shifted the responsibility for his departure onto the shoulders of the youngest members of the complot, writing, "March-May 1963: revolution at Cahiers, Jean-Louis Comolli and Jean-André Fieschi push me towards the

15 Jean-Louis Comolli, "L'autre ailleurs (Le Procès de Jeanne d'Arc)," Cahiers du cinéma no. 143 (May 1963), pp. 42-49, here p. 46.

16 See Antoine de Baecque and Noël Herpe, Éric Rohmer (Paris: Stock, 2014), pp. 146-154.

17 Comolli, Cinéma contre spectacle, p. 19 [pp. 58-59]. 
exit."18 Douchet was equally rueful: "I took it poorly that some of the young critics I brought on stabbed me in the back." ${ }^{19}$

Under Rivette, Cahiers' openness towards new theoretical tendencies was reflected above all in three interviews carried out with Roland Barthes, Claude Lévi-Strauss and Pierre Boulez in the first months of his stewardship. ${ }^{20}$ But it also entailed opening the journal up to new critical voices - a move partly necessitated by the replenishment of the stock of writers diminished by the departure of Rohmer and Douchet. After moving to Paris in 1962 and finding work in a hospital, Narboni gravitated around the Cahiers group and even made a brief appearance in Rohmer's La carrière de Suzanne (for which Comolli was assistant director), but his entry into the journal did not come until after Rivette's "putsch" — when he made a short contribution to the multi-authored text "Paralipomènes aux Oiseaux" in November $1963 .{ }^{21}$ His first critical texts came early the following year, and his first two reviews exemplify the twin critical tasks that would consume the review in this period. In February 1964, the novice critic was given the chance to review Godard's Le Mépris, and, whilst showering the film with dithyrambic praise, he also provided a structural analysis of the work: founded on the "unrelenting mechanism of a question-and-answer game," the film's dialogues have less to do with "conversation than with incitation and evasion," a structuring principle that gives rise both to the "discrepancy" (décalage) between question and answer (as represented by the frequent interpolations made by the translator) and, figuratively, to the "incessant coming-and-going of the characters, in the pursuit that they conduct without respite, always hard-pressed, out of synch, on the heels of each other." ${ }^{22}$ The following month, with "Mankiewicz à la troisième personne," Narboni sought to read Joseph L. Mankiewicz's œuvre from the standpoint of literary modernism: far from being marked by elegance, equilibrium and lucidity, his

18 Éric Rohmer, “Chronologie pour les Cahiers du cinéma” (unpublished, 2007). Cited in De Baecque/Herpe, Éric Rohmer, p. $15^{2}$.

19 Jean Douchet, interviewed in Les Inrockuptibles, October 27, 1999. Cited in De Baecque/ Herpe, Éric Rohmer, p. $15^{2}$.

20 For more on these encounters, see Chapter 14.

21 See Jean-Louis Comolli, Jean Douchet, Jean-André Fieschi, Fereydoun Hoveyda, Jean Narboni and Claude Ollier, "Paralipomènes aux Oiseaux," Cahiers du cinéma no. 149 (November 1963), pp. 38-44. When interviewed, Narboni also remembered having an earlier review of Otto Preminger's Where the Sidewalk Ends rejected when Rohmer was still editor, but with the message that he should continue submitting pieces to Cahiers. Interview with Jean Narboni, March 3 , 2014 .

22 Jean Narboni, "Ouvert et fermé (Le Mépris)," Cahiers du cinéma no. 152 (February 1964), pp. 66-69, here p. 68. 
films are striated by "violence and delirium" and subject to the incursion of “obscure forces." For Narboni, the blank neutrality of Mankiewicz's mise en scène has a deep affinity with the writing of F. Scott Fitzgerald: the framing and camera movements of the former "have nothing very remarkable" about them while the literary style of the latter escapes "all narrative artifice, both in process and technique." ${ }^{23}$

These two texts tacitly form the program that governed Cahiers' critical work in the period 1964-1967: firstly, to defend the work of the journal's favored Hollywood auteurs at a moment when the studio system was in crisis, and secondly to support the "new waves" that were flourishing not only in France but also in Italy, Quebec, Eastern Europe, Japan, Brazil and elsewhere. Retrospectively, Narboni speaks of this period as "a historical moment that will never be reproduced" in which multiple "geological layers" coexisted: the last films of the titans of classical Hollywood (Hawks, Walsh, Ford), the latest works of the first generation of modernist filmmakers (Antonioni, Bergman, Buñuel), and finally the debut offerings of the "young cinema," directors in their twenties and thirties who first came to prominence in this decade. ${ }^{24}$

\section{The New "Hitchcocko-Hawksians"}

For all their love of the American cinema, it did not escape the Cahiers critics in the early 1960 s that the studio system was in a state of terminal crisis. One of the most ambitious special issues of Rivette's editorship was precisely devoted to this question. Clocking in at 276 pages, "Situation II du cinéma américain" (December 1963-January 1964) included the round table "Sept hommes à debattre," where Truffaut famously declared: "We used to say that we liked the American cinema but its filmmakers were slaves; what would it be like if they were free men? Well, the moment they become free they make lousy films." ${ }^{25}$ In the same issue, Comolli called for a rethinking

23 Jean Narboni, "Mankiewicz à la troisième personne," Cahiers du cinéma no. 153 (March 1964), pp. 27-31, here p. 30 .

24 Interview with Jean Narboni, March 3, 2014.

25 François Truffaut, in Claude Chabrol, Jacques Doniol-Valcroze, Jean-Luc Godard, Pierre Kast, Luc Moullet, Jacques Rivette and François Truffaut, "Sept hommes à debattre," Cahiers du cinéma no. 150-151 (December 1963-January 1964), pp. 12-23, here p. 20. Translated as "Questions about American Cinema," trans. David Wilson, in Jim Hillier (ed.), Cahiers du Cinéma vol. II: The 196os: New Wave, New Cinema, Reevaluating Hollywood (London: BFI, 1986), pp. 172-180, here p. 176. 
of American cinema in general. If the industrial model had collapsed, there at least remained a small number of filmmakers whose work was of critical interest: "There is no American cinema. At least, not any more. There are only ten, fifteen, twenty filmmakers, artists, with œuvres. Only these men of cinema have made the cinema, and they still do." ${ }^{26}$ Later, Comolli issued a guarded defense of Cleopatra, the lavish symbol of the collapse of the studio system, while admitting that the finished film resembled a "nightmare of the creator with his creation." ${ }^{27}$ Aside from exceptional cases such as John Ford, the hommes de cinéma defended by Comolli and Narboni were contiguous with the critical taste of the previous generation of Cahiers critics. The generation of Truffaut and Rivette had been dubbed "Hitchcocko-Hawksians" within the journal, so it is fitting that foremost among the directors whose work continued to be championed by Comolli and Narboni were none other than Hitchcock and Hawks. In contrast, however, to the 1950 s critics, who tended to emphasize the classical aspect of these filmmakers, ${ }^{28}$ Comolli and Narboni took an interest in their relationship with aesthetic modernity, a trait that becomes more evident with the onset of Hollywood's post-classical decadence.

The response by Comolli to Man's Favorite Sport is illustrative of this tendency. While the release of Hawks' film prompted Cahiers to run an interview with the director (conducted by Serge Daney and Louis Skorecki) and a review of the film by Michel Delahaye, ${ }^{29}$ Comolli took the opportunity to revisit his stance on Hawks' œuvre, arguing that 'from his first steps through to his latest offspring, Hawks has never been either a classic in the classic sense of the term, or the master of 'simplicity,' and even less of the obvious [l'évidence] (something that has been inferred from a misunderstanding of Rivette's idea). His only evidence is that of the lynx: he sees without being seen. ${ }^{.30}$ Far from being a "worthy figure with deep humanitarian

26 Jean-Louis Comolli, "L’Amérique à découvert," Cahiers du cinéma no. 150-151 (December 1963-January 1964), pp. 217-224, here p. 217.

27 Jean-Louis Comolli, “Cléopatre, le jeu, l'échec," Cahiers du cinéma no. 153 (March 1964), pp. 32-40, here p. 40.

28 See, for instance, Claude Chabrol and Éric Rohmer, Hitchcock (Paris: Éditions universitaires, 1957).

29 See Serge Daney, Jean-Louis Noames and James R. Silke, "Entretien avec Howard Hawks," Cahiers du cinéma no. 16o (November 1964), pp. 54-60; and Michel Delahaye, "D'un sport à l'autre (Man's Favorite Sport)," Cahiers du cinéma no. 16o (November 1964), pp. 80-81. "Jean-Louis Noames" was the pseudonym used by Skorecki in the early 1960 s.

30 Jean-Louis Comolli, "H.H., ou l'ironique," Cahiers du cinéma no. 16o (November 1964), pp. 49-52, here p. 49. Translated as "The Ironical Howard Hawks," trans. Norman King, in Hillier (ed.), Cahiers du cinéma vol. II, pp. 181-186, here p. 182. 
concerns," as his devotees often describe him, Hawks is, in Comolli's view, "the most discreet humorist of the century," and in this sense there is no distinction between his comedies and his "serious" films, since both bear the same tacit message: "In the service of the lie, cinema speaks the truth; it lies in the service of truth and can thus serve it better."31 The perpetual play of reversals and false leads required to dissimulate this message means that, for Comolli, Hawks would be "a faux classic if he had not always been a true modern." ${ }^{32}$

With the release of Red Line 7000 in July 1966, Comolli and Narboni had a more difficult task in defending their cherished auteur: the film, focusing on the sport of stock-car racing, was critically reviled and is still one of the most neglected works in Hawks' œuvre. Produced independently with the director's own money, the economy of Red Line zooo betrays itself repeatedly in the film's cheap production values. And yet Comolli, resisting any idea of a decline in Hawks' filmmaking, deems that the director has made a virtue of necessity: the repetition of the same shots standing in for different racetracks augments the "impression of monotony" that prevails throughout Red Line 70oo: "weakness becomes strength, and form. Repetition becomes structure. Monotony turns into vertigo." 33 The racetracks are a "perpetual mechanism, an empty movement" and thus stand in for the dramaturgical principle of the film as a whole. ${ }^{34}$ It is for this reason that Hawks' modernity, and even his youthfulness, remains intact in this film. Narboni likewise defended the "modernity" of Red Line 7ooo but did so through a discussion of time, speaking of Hawks' "tenacious, obstinate, repetitive temporality, moved forward by accumulation and tautology, rather than straight progression or the sudden take-off," which makes Red Line appear to be "the work of someone ageless." 35 For Narboni, Hawks' cinema can only be accepted or rejected in its entirety, since it constitutes "a vast nervous system, a field of forces or tiered networks." ${ }^{36}$ That both Comolli and Narboni's advocacy of Hawks tended more and more towards abstraction was, however, symptomatic of the increasing difficulties they

33 Jean-Louis Comolli, "Cherchez l'Hawks (Red Line 70oo)," Cahiers du cinéma no. 180 (July 1966), pp. 24-28, here p. 24 .

34 Ibid.

35 Jean Narboni, "Contre la montre (Red Line 7ooo)," Cahiers du cinéma no. 18o (July 1966), pp. 28-30, here pp. 28, 30. Translated as “Against the Clock," trans. Diana Matias, in Hillier (ed.), Cahiers du Cinéma vol. II, pp. 216-219, here pp. 217-218.

36 Ibid., p. 3 o. 
had, as the Vietnam War intensified, in defending a filmmaker whose politics were remote from their own. At the same time as the duo praised Red Line 7000 , the high-profile Nouvel Observateur critic Michel Cournot attacked Hawks for espousing a pro-war ideology. ${ }^{37}$ Comolli retorted that Hawks was a "filmmaker of intelligence and subtlety, of irony and non-convention (the total opposite of [Robert] McNamara), ${ }^{38}$ but the contradiction broke out more forcefully the next year. With the release of ElDorado (1967), Comolli, Narboni and Bertrand Tavernier had the opportunity to interview Hawks. Here, the filmmaker confirmed his plans to make a film on the Vietnam War (pending approval from the "War Department") and commented: "It is a totally new war, you know, it's not like anything we've seen before. The Americans are fighting against little people, who are acclimated to their country." ${ }^{39}$ A postscript to the interview gave the Cahiers editors' viewpoint on this project: it represented "a political act, whose politics we condemn." At the same time, however, they acknowledged that "the position taken by H.H. on an event whose urgency solicits those of us who are on the other side of the barricade is itself very Hawksian. ${ }^{\text {"40 }}$ Notwithstanding Hawks' remarks, Comolli gave a cautious defense of El Dorado in the same issue of Cahiers, arguing that it is the director's "refusal of sentimentalism" that allows us "not to despair of Howard Hawks."11

The paradoxes of Cahiers' support for the late Hawks were also present, a fortiori, in their continued advocacy of Hitchcock and became manifest with the release of Torn Curtain in 1967. That the "master of suspense" had delivered an overtly anti-communist film, presenting the GDR as a terrorist state and relaying a series of Cold War clichés about life behind the "Iron Curtain," seemed not to perturb a pair of critics who by this point identified squarely with the radical left in France. Emphasizing the film's surreal, dream-like qualities, Narboni asserted that Torn Curtain's "fantastic round-trips and adventurous itineraries" linked it with a less "serious" but no less authentic vein in Hitchcock's œuvre (that of campy spy thrillers like $A$

37 Michel Cournot, “La verticale d'Hanoï," Le Nouvel Observateur, July 6, 1966.

38 Jean-Louis Comolli, “Toujours pour... Hawks!” Cahiers du cinéma no. 181 (August 1966), p. 4. Cournot replied to this text, insisting that "On the evidence Red Line 7000 appears to me to be a monument of idiocy." Michel Cournot, "Et toujours contre!," Cahiers du cinéma no. 181 (August 1966), p. 4.

39 Howard Hawks, interviewed by Jean-Louis Comolli, Jean Narboni and Bertrand Tavernier, "Entretien avec Howard Hawks," Cahiers du cinéma no. 192 (July-August 1967), pp. 14-21, 67-68, here p. 68.

40 Ibid.

41 Jean-Louis Comolli, “L'envers de l'Eden," Cahiers du cinéma no. 192 (July-August 1967), p. 22. 
Lady Vanishes and The Man Who Knew Too Much). The thin, substance-less characters reminded the critic of Giacometti's "thread-like statues," and he avowed that "Torn Curtain affects me through this emaciation, this melting, this loss of substance imposed on characters and on situations." ${ }^{\text {42 }}$ Comolli similarly highlighted the dream-world in which the film seems to transpire: the journey undertaken by Paul Newman, fleeing the authorities, does not take place in East Germany but in "Hitchcockland," a site "of images, of the dream, and of dream representation, of the projections and of the constitution of phantasms in the setting." Moreover, the inversion of Hitchcock's habitual schema for the spy thriller (this time an American is attempting to reveal the state secrets of an Eastern bloc government) results in a "very Hitchcockian irony and perversion" and a "systematic blurring of significations" which render the political message of the film "rather more ambiguous than a purely political logic would impose."43

\section{Defending the Nouveaux Cinémas}

This insistence on a continued advocacy of the late work of the Hollywood masters, even in the face of subject matter that is politically hostile to the Cahiers critics' own outlook, would prove to be the template for the "symptomatic" analyses of classical Hollywood films during the journal's Marxist period. But it also brought with it the need for a certain contorted critical logic, resting on a taste for paradox, twisted argumentation and counter-reading. When it came to the other component of Comolli/Narboni's critical project of the mid- to late-196os - their defense of the "new cinemas" (nouveaux cinémas, pluralized to acknowledge the international character of the movement) - the contradictions in their critical appraisals are less immediately apparent. Often, the critics were in profound political and generational synchrony with their subjects. Here too, however, occasional "perverse" readings of films were generated in order for consistent support to be given to a director. Nonetheless, the nouveaux cinémas generally gave Comolli and Narboni the opportunity to support and foster a wave of filmmakers to whom they felt closely attuned. Moreover, as Narboni would

42 Jean Narboni, "La machine infernale," Cahiers du cinéma no. 186 (January 1967), p. 35. Translated as "The Infernal Machine," Cahiers du Cinéma in English no. 10 (May 1967), p. 51.

43 Jean-Louis Comolli, “Le rideau soulevé, retombé (Torn Curtain)," Cahiers du cinéma no. 186 (January 1967), pp. 36-39, here pp. 36, 39. Translated as “The Curtain Lifted, Fallen Again," Cahiers du Cinéma in English no. 10 (May 1967), pp. 52-55, here pp. 52, 55. 
write nearly 40 years later, their discovery and promotion of these figures should rightly be seen as one of the most important accomplishments in the history of Cahiers. ${ }^{44}$ The journal, meanwhile, saw its own generational change in this period: in 1965, Rivette vacated his post as editor-in-chief in order to focus his attention on the production of La Religieuse, leaving the position to Comolli, by that point the most dynamic critical voice at Cahiers. Narboni officially joined him in the role in 1968, but this was a change in title only, as he was already a key editorial presence in Cahiers by the mid-196os. ${ }^{45}$

If Cahiers' support for the French nouvelle vague was unflagging after the "putsch" against Rohmer, the idea that a nouveau cinéma existed outside of France took longer to filter through to the journal's critics. Italy was the first nation where a "young national cinema" was detected, with Narboni and Comolli discussing Prima della rivoluzione by Bertolucci and I Fidanzati by Olmi in July 1964-although here they were already following in the footsteps of André S. Labarthe, who as early as 1962 had noted the existence of a new, post-neorealist generation of filmmakers in the country. ${ }^{46}$ Comolli and Narboni inscribed the work of these directors in the country's neorealist heritage: despite their many differences, both Bertolucci and Olmi exhibit the "refusal of priorities' which André Bazin saw as the essence of neorealism. ${ }^{47}$ But their work also undercut a critical cliché distinguishing the "'positive,' engaged, affirmative" young Italian cinema from the "confusions and uncertainties" of its French equivalent (the work of Godard and Resnais in particular). Rather, the two films, for Comolli/Narboni, exemplify the "dialectic of doubt and affirmation" operative among young Italian filmmakers. ${ }^{48}$

This same dialectic permeated through to emerging filmmakers around the world, as discussion of new auteurs such as Gilles Groulx, Jerzy Skolimowski, Věra Chytilová and Glauber Rocha took an increasingly prominent place on the pages of Cahiers. By 1966, Comolli was so confident in the burgeoning promise of this cinema that he could claim in an editorial:

44 Jean Narboni, "Les futurs antérieurs" in Jean-Louis Comolli, Gérard Leblanc and Jean Narboni, Les années pop: Cinéma et politique: 1956-1970 (Paris: BPI/Centre Pompidou, 2001), pp. 9-20.

45 Interview with Jean Narboni, March 18, 2014. Between November 1965 and September 1968, Jean-Louis Ginibre (an editor at Jazz Magazine, which had the same owner as Cahiers at this time), was credited as a co-editor-in-chief alongside Comolli, but this was a titular function only, and he never wrote for Cahiers or had any role in directing its critical line.

46 André S. Labarthe, "Avant-propos," Cahiers du cinéma no. 131 (May 1962), pp. 1-2. The entire issue that month was dedicated to the theme "Situation du cinéma italien."

47 Jean-Louis Comolli and Jean Narboni, "Retour en Italie," Cahiers du cinéma no. 157 (July 1964), pp. $29-37$, p. 36.

48 Ibid., p. 37 . 
"That there exists, today, a 'new' cinema is something that nobody will contest tomorrow." While the critic recognized that the entire history of the cinema had been marked by fertile periods of formal innovation and is thus an eternal struggle between the forces of "the new" and "the old," he also makes the optimistic historical claim that "the cinema has never before seen arise [...] such an army of conquerors. And never before, at any rate, has the birth of so many filmmakers been granted so much attention." Of particular interest for Comolli was the rise of filmmakers from Quebec and Brazil, who found themselves at the forefront of "a combat that is not only of an artistic nature, but which concerns a society, an ethos, a civilization" and thus constituted genuine "cinemas of revolution." ${ }^{\text {49 }}$

The pretext for his editorial was the decision to host a "Semaine des Cahiers" in April 1966: a week-long series of screenings highlighting films from the nouveaux cinémas that had struggled to find regular distribution in France. In May, Narboni gave the historical context to this new crop of filmmakers, arguing for "three ages" of modern cinema in the post-war era: Italian neorealism, the French nouvelle vague and the international nouveau cinéma. If Italian neorealism represented a moment where "the author was effaced to the benefit of the outside world, with its lacunae, its gaps, its discontinuity" and the nouvelle vague represented the "passionate and violent" individual reaction against the cinéma de qualité, then the originality of the nouveau cinéma resides in occupying "the crossroads between these two great movements. ${ }^{\prime \prime}$ Correspondingly, Narboni finds the movement's vitality particularly present in the work of three filmmakers Bertolucci, Skolimowski and Bellochio, whose films represent, respectively, the critical, oneiric and parabolic paths towards cinematic autobiography.

Two texts from 1967 also strove to give an account of the nouveau cinéma-now, in a reflection of the radicalized climate pervading both the journal and the country in the months leading up to May 1968, from a perceptibly more political angle. Comolli's “Une morale de la dépense" argued that the key aspect uniting the various nouveaux cinémas, and the quality that gives this global movement a revolutionary status, is "the awareness among the new filmmakers of the need to reevaluate its relationship with society, in its double guise as producer and consumer." ${ }^{m 1}$ Following on from

49 Jean-Louis Comolli, "Situation du nouveau cinéma, 1," Cahiers du cinéma no. 176 (March 1966), p. 5 .

50 Jean Narboni, "Les trois âges," Cahiers du cinéma no. 178 (May 1966), pp. 58-59.

51 Jean-Louis Comolli, "Une morale de la dépense," Cahiers du cinéma no. 190 (May 1967), pp. 59-6o, here p. 59. Translated as "A Morality of Economics," trans. Diana Matias, in Hillier (ed.), Cahiers du Cinéma vol. II, pp. 290-293, here p. 291. 
the model adopted by Godard, there was also increasing consideration given to the new ways these films could be financed, in which a radically decreased budget would not only allow for the existence of a marginal cinema but also result in a much more intrinsically politicized art form..$^{2}$ Narboni, for his part, viewed the nouveau cinéma within a broader cinematic movement towards "impertinence" - with the critic playing on the dual meaning of the word, denoting both impudence or effrontery and, on a more strictly linguistic level, the voiding of signification. Films such as Belle de jour, La Chinoise and Nicht versöhnt offered a new relationship between signifier and signified that is much less founded in the analogical relationship between referent and representation, and more focused on exploring new possibilities for cinematic writing. 53

If there was one representative of modernist cinema whose films drew critical attention during this period and whose work was decisive in shaping the critical categories established in "Cinéma/idéologie/critique," it was a figure who was neither young nor particularly new to the cinema. Nonetheless, Ingmar Bergman's films in the late 196os attested to a spirit of formal innovation and social critique that could hardly leave the Cahiers critics indifferent. Comolli, in particular, followed the director's career closely, devoting texts to The Silence, Persona and Hour of the Wolf that played a key role in forming the critic's broader understanding of the cinema. Comolli's long text on the first of these films, "Bergman anonyme" from June 1964, can in retrospect be seen as a turning point in the critic's trajectory, away from the phenomenological humanism of his early texts and towards the "political modernism" of his writings in the second half of the 1960 and the 1970s. The Silence, for Comolli, is a new departure for Bergman, in which the thematic obsession that marks the Swede's entire œuvre - the idea of regression-is no longer veiled but openly affirmed. Moreover, the "closed circuit" between spectator and film that Bergman creates with The Silence is such that "the spectator sees himself introduced into the mirror, into the film, in order to become, in turn, a mirror of the spectator. The spectator in the film and the spectator in the cinema repel each other and reflect each other, ceaselessly hurtled back and forth between reality and illusion, between a dynamic vision and a regressive vision." 54

52 Ibid., p. 6 o.

53 Jean Narboni, "Vers l'impertinence," Cahiers du cinéma 196 (December 1967), p. 4. Translated as “Towards Impertinence," trans. Norman King, in Hillier (ed.), Cahiers du Cinéma vol. II, pp. 300-302.

54 Jean-Louis Comolli, "Bergman anonyme (Les Communiants, Le Silence)," Cahiers du cinéma no. 156 (June 1964), pp. 30-39, here p. 36. 
The idea of reflection also dominated Comolli's response to Persona. Discussing the images of a projector's carbon filaments that begin the film, Comolli exclaims: "never was the screen a more faithful mirror. We are in front of it, and what it shows us is in back of us. It and we: transparent phantoms." ${ }^{55}$ Although the film properly speaking starts after these images, the sense of doubt in the spectator aroused by the self-reflexivity of this opening sequence lingers and is reawakened when, halfway through the screening, the filmstrip appears to break up and catch fire, with the rest of the film proceeding as the inversion of Persona's first half. Awestruck in wonder at the modernism of Persona - which is still powerful today, even if its formal devices have become banalized through imitation-Comolli would have recourse to a more elaborate mode of argumentation in defending Shame in 1969. Here he was prompted by Cinéthique's Jean-Paul Fargier, writing for the Tribune socialiste, who censured the film for its "idealist humanism" and overly abstract denunciation of the horrors of war-an aesthetic approach which, in the end, "does nothing to lead people out of the obscurantism in which the cinema plunges them. ${ }^{56}$ Comolli's affirmation of the film's value from a historical materialist perspective was not helped by Bergman himself, who, when asked about his politics in an interview published in Cahiers, stated, "My personal political position absolutely only concerns myself. As an artist, I am terribly anguished by what is happening right now, but I cannot place myself under any banner."57 Indeed, the critic detects a paradox within Bergman's œuvre: while his films become more radical, his discourse on them has become more paltry, purveying vague ideological notions about "the World" and "Man." If Bergman is to be believed about his own work, then his film does indeed, as Fargier claims, possess a "reactionary message." In Comolli's line of argument, however, "the very fact that Bergman says this outside the film inclines me to think that the film, outside of Bergman, does not say it." ${ }^{n 8}$

It is precisely against Bergman's own interpretation of his work, then, that Comolli defends the film, and in doing so he makes specific reference

55 Jean-Louis Comolli, "Le Fantôme de Personne (Persona)," Cahiers du cinéma no. 188 (March 1967), p. 20. Translated as "The Phantom of Personality," Cahiers du Cinéma in English no. 11 (September 1967), pp. 31-33.

56 Jean-Paul Fargier, "La Honte," Tribune socialiste, cited in toto in Comolli, "Dernier acte, encore," p. 56 .

57 Ingmar Bergman, interviewed by Stig Björkman, Torsten Manns and Jonas Sima, "La mort à chaque aube: Entretien avec Ingmar Bergman," Cahiers du cinéma no. 203 (August 1968), pp. 49-56, here p. 53. The interview was reprinted in French translation (by Kerstin L. Bitsch) from the Swedish film magazine Chaplin.

$5^{8}$ Comolli, "Dernier acte, encore," p. 56. 
to Macherey's concept of "literary production," which rejects a demiurgic, "auteurist" vision of aesthetic creation in favor of a historically and socially contextualized account of the process of "producing" works of art. ${ }^{59}$ For Comolli, the reason for the abstract, historically decontextualized manner of evoking military conflict in Shame is that it should actually be read as a mere echo of the film's principal storyline: the "war" between the husband-and-wife couple played by Liv Ullmann and Max von Sydow. The critic thus advocates a psychoanalytic reading of Bergman's film: "All the war scenes in Shame are filmed like a nightmare, not because the film means to say: war is a nightmare, which is doubtless what Bergman wanted to make it say, but because they are the matter of the couple's nightmare, the oneiric form of their destruction." ${ }^{60}$ It is tempting, as Lellis does, to see this review as "a direct example of Cahiers' being forced on the defensive by a more radical segment of French criticism," ${ }^{61}$ but it is also an example of the critical dexterity the journal could practice during this period, defending a film against the author's own interpretation of it. Readings such as this would contribute to the subtlety and complexity of the categories produced in "Cinéma/idéologie/critique"-Bergman's Persona, it should be recalled, is specifically invoked as an example of a "category (c)" film requiring an "against the grain" critical reading.

\section{"Le détour par le direct"}

The text that would be the most decisive precursor for the October 1969 editorial, however, was Comolli's two-part exploration of "direct" cinema, "Le détour par le direct." Here the Cahiers critic discerns a "certain tendency" in the cinema of the late 1960s: the "formal vanguard" of fiction film and the "direct" tradition of documentary cinema begin to share the same filmmaking techniques. Not only did films such as L'Amour fou by Rivette, Partner by Bertolucci or Silence and Cries by Jancsó adopt shooting practices derived from the documentary aesthetic but, conversely, the "non-fiction" films of Perrault, Eustache or Rouch came to borrow narrative devices from modernist fiction films. For Comolli, it is as if "the traditionally separate and even opposing fields of 'documentary' and 'fictional' films were interpenetrating

59 See Pierre Macherey, Pour une théorie de la production littéraire (Paris: Maspéro, 1966). Translated as $A$ Theory of Literary Production.

60 Comolli, "Dernier acte, encore," p. $5^{8 .}$

61 Lellis, Bertolt Brecht, Cahiers du Cinéma and Contemporary Film Theory, p. 75. 
more and more and intermingling in innumerable ways. It is as if they were engaged in a vast process of exchange, a reciprocal system where reportage and fiction alternate or conjugate within one and the same film." ${ }^{62}$

Since the time of this article, Comolli has maintained a complex relationship with "direct" cinema, one that was no doubt fostered by his own involvement in documentary filmmaking with André S. Labarthe, whose series "Cinéastes de notre temps" he credits with having "put into practice the mutual perversion of documentary and fiction." ${ }^{63}$ The Cahiers critic directed episodes on Pierre Perrault and Miklós Jancsó for the series (both of whom featured prominently in his article) and completed the "direct" documentary Les deux Marseillaises with Labarthe in 1968, which focused on the June 1968 legislative elections, overwhelmingly won by the Gaullists. ${ }^{64}$ Comolli's practical experience in this area did not, however, leave him with any illusions about the virtues of direct cinema. In "Le détour par le direct" he claims that, while "in its raw form direct cinema is present in every scrap of reportage filming, just as the cinema in its raw form is present in any sequence of images," there is a "basic deception" in direct cinema: that it can claim to "transcribe truly the truth of life." For Comolli, the very act of filming a given situation serves irrevocably to transform it, and thus a clear antinomy between the direct cinema and a cinema of "aesthetic manipulation" is impossible to maintain. If the direct method has a drawback, it is, for Comolli, not through any supposed "lack of honesty" towards the filmed material but rather through an "excess of respect" and a "lack of audacity." The very act of filming already constitutes a form of "manipulation" that changes - and even "perverts" - the nature of the event being filmed, but "direct cinema" suffers from a palpable neglect of the very "principle of perversion" that is the foundation of the cinema. ${ }^{65}$

In the documentary cinema, Comolli finds perhaps the most startling example of an effective use of direct filmmaking in the 10-minute short $L a$ Reprise du travail aux usines Wonder, made by Jacques Willemont. The film consists of a single shot, the length of a reel, showing factory workers at the Wonder battery plant returning to work after the end of a (victorious) strike. One woman, however, resists: tears streaming down her face, she is vocally unwilling to return to the daily oppression of factory life after having tasted the emancipatory experience of the strike, despite the encouragement of the

62 Comolli, “Le détour par le direct (1)," p. 48 [p. 225].

63 Comolli, "Le détour par le direct (2)," p. 44 [p. 241].

64 For a more in-depth disussion of Comolli's filmmaking, see Chapter 13.

65 The above quotes are all from Comolli, "Le détour par le direct (1)," p. 48 [pp. 225-226]. 
bosses, union leaders and even her fellow workers. If this short film achieves a fiction effect through documentary means, the reverse operation takes place in films such as Silence and Cries and L'Amour fou, and Comolli provides detailed discussions of the shooting style of both filmmakers. Rivette's film is of particular interest for introducing montage effects between the scenes of theater rehearsals, shot on $16 \mathrm{~mm}$ by a documentary crew headed by Labarthe, and the "real life" footage, shot on $35 \mathrm{~mm}$ with a standard professional crew: here, paradoxically, it is the "artificial situation" of the theater that is given a documentary treatment, while the off-stage scenes become dream-like through their marked coding as "fictional" within the formal system established for the film.

More broadly, Comolli sketches a mini-history of the cinema seen through the prism of the direct method, whose techniques can be traced back to the practice of Vertov and Eisenstein in the Soviet silent cinema. The rise of direct cinema (ushered in by the advent of portable synch sound in the early 196os) represents, for Comolli, a formal revolution on the same level as the development of sound cinema in the late 1920s. In contrast to the advent of sound, direct cinema imposes itself through a "diffuse operation, a subtle reversal, an insidious change. ${ }^{n 6}$ Its ideological effects are no less powerful, however, and have shaken what Comolli calls the "system of representation" (here meaning conventional narrative cinema) to its core: "In the case of the talkie it was the language of the ruling class and the dominant ideologies which conquered the cinema. With synchronized sound it was the cinema which conquered speech, all speech, the speech of both sides, that of the workers and that of the bosses." ${ }^{\prime 6}$ There is a certain idealism in the excesses of this claim, ascribing opposed class interests to different technologies of sound cinema, and Comolli does not pursue this particular line of thinking, although it does form the germ for his later, more influential text "Technique et idéologie." The later series of articles is also specifically anticipated in Comolli's contestation of Marcelin Pleynet's reproach of the cinema in Cinéthique for being the "natural ideological accomplice" of the existing world of the bourgeoisie by virtue of its "duplicative nature." 68 This is the first time Cahiers addresses the Tel Quel critic's remarks and is evidence of the immediate impact the interview had on the journal. As he will also do in "Technique et idéologie," Comolli flatly repudiates Pleynet; here, interestingly, he turns to Macherey in order to do so, and in particular

68 Comolli, “Le détour par le direct (2)," p. 45. 
the literary theorist's claim that an "image which conforms absolutely to the model merges with it and loses its status as image; it remains such only by virtue of the gap separating it from what it imitates." ${ }^{\prime 69}$ It is in this innate gap or "discrepancy" (décalage) between image and referent— the discussion inevitably recalls Bazin's invocation of the cinema as an "asymptote" of reality ${ }^{70}$ - that Comolli sees a possibility for the cinema to avoid being the ideological reduplication of the capitalist status quo: not only does the cinema "reproduce" only a small slice of the world as it really exists, it is also "the product of a particular work operating on images as its basic material, but also on meaning, rhythms, devices, etc." In the best manifestations of direct cinema (whether in "documentary" or "fiction" film practice), the filmed event does not pre-exist the film but is instead produced by the very act of filming. It is therefore an act of "trans-formation" rather than "re-presentation," one that deposes "the world as model of the film by depriving the film of any 'model."' ${ }^{1}$ As in his later, more polemical series of articles, therefore, Comolli here argues for a close relationship between film "technique" and its potential "ideological" repercussions, and "Le détour par le direct" thus stands as the most important theoretical precursor to both "Cinéma/idéologie/critique" and "Technique et idéologie," adumbrating fundamental questions of cinematic representation that would animate Cahiers in the ensuing years.

\section{Works Cited}

Antoine de Baecque and Noël Herpe, Éric Rohmer (Paris: Stock, 2014).

André Bazin, “Une grande œuvre: Umberto D.," in idem., Qu'est-ce que le cinéma? vol. IV: Une esthétique de la réalité: le néo-réalisme (Paris: Éditions du Cerf, 1962), pp. 92-96. Translated as “Umberto D.: A Great Work," in idem., What is Cinema? vol II, trans. and ed. Hugh Gray (Berkeley: University of California Press, 2004), pp. 79-82.

Ingmar Bergman, interviewed by Stig Björkman, Torsten Manns and Jonas Sima, "La mort à chaque aube: Entretien avec Ingmar Bergman," Cahiers du cinéma no. 203 (August 1968), pp. 49-56.

69 Macherey, Pour une théorie de la production littéraire, p. 129 [p. 7o]. Cited in Comolli, "Le détour par le direct (2)," p. 45 [p. 242].

70 See André Bazin, "Une grande œuvre: Umberto D.," in idem., Qu'est-ce que le cinéma? vol. IV: Une esthétique de la réalité: le néo-réalisme (Paris: Éditions du Cerf, 1962), pp. 92-96, here p. 96. Translated as "Umberto D.: A Great Work," in idem., What is Cinema? Vol. II, trans. and ed. Hugh Gray, pp. 79-82, here p. 82 .

71 Comolli, "Le détour par le direct (2)," p. 45 [pp. 242-243]. 
Claude Chabrol and Éric Rohmer, Hitchcock (Paris: Éditions universitaires, 1957).

Claude Chabrol, Jacques Doniol-Valcroze, Jean-Luc Godard, Pierre Kast, Luc Moullet, Jacques Rivette and François Truffaut, "Sept hommes à debattre," Cahiers $d u$ cinéma no. 150-151 (December 1963-January 1964), pp. 12-23. Translated as "Questions about American Cinema," trans. David Wilson, in Jim Hillier (ed.), Cahiers du Cinéma vol. II: The 196os: New Wave, New Cinema, Reevaluating Hollywood (London: BFI, 1986), pp. 172-18o. Hereafter CDC II.

Michel Ciment and Jacques Zimmer (eds.), La critique de cinéma en France (Paris: Ramsay, 1997).

Jean-Louis Comolli, "Grandeur du simple (Sergeant York)," Cahiers du cinéma no. 135 (September 1962), pp. 54-58.

—, "Vivre le film," Cahiers du cinéma no. 141 (March 1963), pp. 14-29.

_-, "La présence et l'absence (Le Petit Soldat)," Cahiers du cinéma no. 141 (March 1963), pp. 54-58.

—, "Vanité de l'art," Cahiers du cinéma no. 142 (April 1963), pp. 54-57.

—, "Lautre ailleurs (Le Procès de Jeanne d'Arc)," Cahiers du cinéma no. 143 (May 1963), pp. 42-49.

—, "L'Amérique à découvert," Cahiers du cinéma no. 150-151 (December 1963-January 1964), pp. 217-224.

—, "Cléopatre, le jeu, l'échec," Cahiers du cinéma no. 153 (March 1964), pp. 32-40.

—, "Bergman anonyme (Les Communiants, Le Silence)," Cahiers du cinéma no. 156 (June 1964), pp. 30-39.

—, "H.H., ou l'ironique," Cahiers du cinéma no. 160 (November 1964), pp. 49-52. Translated as "The Ironical Howard Hawks," trans. Norman King, in CDC II, pp. 181-186.

—., "Situation du nouveau cinéma, 1," Cahiers du cinéma no. 176 (March 1966), p. 5 .

—, "Cherchez l'Hawks (Red Line 7ooo)," Cahiers du cinéma no. 180 (July 1966), pp. 24-28.

—, "Toujours pour... Hawks!" Cahiers du cinéma no. 181 (August 1966), p. 4.

—_, "Le rideau soulevé, retombé (Torn Curtain)," Cahiers du cinéma no. 186 (January 1967), pp. 36-39. Translated as “The Curtain Lifted, Fallen Again," Cahiers du Cinéma in English no. 10 (May 1967), pp. 52-55.

—, "Le Fantôme de Personne (Persona)," Cahiers du cinéma no. 188 (March 1967), p. 2o. Translated as "The Phantom of Personality," Cahiers du Cinéma in English no. 11 (September 1967), pp. 31-33.

—, "Une morale de la dépense," Cahiers du cinéma no. 190 (May 1967), pp. 596o. Translated as “A Morality of Economics," trans. Diana Matias, in CDC II, pp. 290-293.

—, "L'envers de l'Eden," Cahiers du cinéma no. 192 (July-August 1967), p. 22. 
—, "Le détour par le direct," Cahiers du cinéma no. 209 (February 1969), pp. 48-54, and Cahiers du cinéma no. 211 (April 1969), pp. 40-45. Translated as "The Detour through the Direct," trans. Christopher Williams, in idem. (ed.), Realism and the Cinema: A Reader (London: BFI, 1980), pp. 224-244.

—, "Dernier acte, encore," Cahiers du cinéma no. 215 (September 1969), pp. 55-58.

- Cinéma contre spectacle (Lagrasse: Verdier, 2009). Translated as Cinema against Spectacle: Technique and Ideology Revisited, trans. and ed. Daniel Fairfax (Amsterdam: Amsterdam University Press, 2015).

—, interviewed by Daniel Fairfax, "Yes, we were utopians; in a way, I still am...: An Interview with Jean-Louis Comolli (Part 1)," Senses of Cinema no. 62 (April 2012), sensesofcinema.com/2012/feature-articles/yes-we-were-utopians-in-a-way-istill-am-an-interview-with-jean-louis-comolli-part-1/ (accessed January 1, 2021).

—, Une terrasse en Algérie (Lagrasse: Verdier, 2018).

—, Jean Douchet, Jean-André Fieschi, Fereydoun Hoveyda, Jean Narboni and Claude Ollier, "Paralipomènes aux Oiseaux," Cahiers du cinéma, no. 149 (November 1963), pp. 38-44.

—, Gérard Leblanc and Jean Narboni, Les années pop: Cinéma et politique: 1956 6-1970 (Paris: BPI/Centre Pompidou, 2001).

— and Jean Narboni, "Retour en Italie," Cahiers du cinéma no. 157 (July 1964), pp. 29-37.

Michel Cournot, "La verticale d'Hanoï," Le Nouvel Observateur, July 6, 1966.

Michel Delahaye, "D'un sport à l'autre (Man's Favorite Sport)," Cahiers du cinéma no. 160 (November 1964), pp. 80-81.

Howard Hawks, interviewed by Serge Daney, Jean-Louis Noames and James R. Silke, "Entretien avec Howard Hawks," Cahiers du cinéma no. 160 (November 1964), pp. 54-6o.

- , interviewed by Jean-Louis Comolli, Jean Narboni and Bertrand Tavernier, "Entretien avec Howard Hawks," Cahiers du cinéma no. 192 (July-August 1967), pp. 14-21, 67-68.

André S. Labarthe, “Avant-propos," Cahiers du cinéma no. 131 (May 1962), pp. 1-2.

George Lellis, Bertolt Brecht, Cahiers du Cinéma and Contemporary Film Theory (Ann Arbor, MI: UMI Research Press, 1982).

Pierre Macherey, Pour une théorie de la production littéraire (Paris: Maspéro, 1966). Translated as A Theory of Literary Production, trans. Geoffrey Wall (London: Routledge, 1978).

Jean Narboni, “Ouvert et fermé (Le Mépris)," Cahiers du cinéma no. $15^{2}$ (February 1964), pp. 66-69.

—, "Mankiewicz à la troisième personne," Cahiers du cinéma no. 153 (March 1964), pp. 27-31.

—, "Les trois âges," Cahiers du cinéma no. 178 (May 1966), pp. 58-59. 
—, "Contre la montre (Red Line 70oo)," Cahiers du cinéma no. 180 (July 1966), pp. 2830. Translated as "Against the Clock," trans. Diana Matias, in CDC II, pp. 216-219. —, "La machine infernale," Cahiers du cinéma no. 186 (January 1967), p. 35. Translated as “The Infernal Machine," Cahiers du Cinéma in English no. 10 (May 1967), p. 51.

—, "Vers l'impertinence," Cahiers du cinéma 196 (December 1967), p. 4. Translated as “Towards Impertinence," trans. Norman King, in CDC II, pp. 300-302.

—, "Les futurs antérieurs" in Jean-Louis Comolli, Gérard Leblanc and Jean Narboni, Les années pop: Cinéma et politique: 1956-1970 (Paris: BPI/Centre Pompidou, 2001), pp. 9-20.

Jacques Rivette, “Génie de Howard Hawks," Cahiers du cinéma no. 23 (May 1953), pp. 16-23. Translated as "The Genius of Howard Hawks," trans. Russell Campbell and Marvin Pister, in Jim Hillier (ed.), Cahiers du Cinéma, the 1950s: Neo-Realism, Hollywood, New Wave (Cambridge, MA: Harvard University Press, 1985), pp. 126-131. 